\title{
W. Paterson
}

In this patient the electro-encephalogram was of great value and helped to substantiate the diagnosis. The involvement of cranial nerves 9 , Io, II and 12 in the posterior fossa is the classical syndrome of Collet and Siccard, 9, Io and II being due to jugular bulb thrombosis, and $\mathrm{I}_{2}$ to its extension in the posterior fossa. There is now considerable recovery of the nerves involved with the exception of the left recurrent laryngeal which is characteristic of this condition.

\section{Summary}

A case of intracranial thrombophlebitis complicating peritonsillar abscess is described. Electro-encephalography was of great value in the diagnosis. Complete resolution was obtained with intensive penicillin therapy.

I am indebted to Mr. G. S. Seed for permission to publish this case record and for help in its preparation.

Dr. M. J. Parsonage was responsible for the E.E.G. report and gave advice in the diagnosis and management of the condition.

\section{REFERENCES}

Key-Åberg, H. (1948) Acta oto-laryng. (Stockh.), Suppl., 67, p. 41. VirTANEN, V. S. (1949) Ibid., Suppl. 80. 


\section{GENERAL NOTES}

\section{OLD ILLUSTRATION BLOCKS}

Ir is our custom to destroy blocks after three years. It may be that some authors would like to have their blocks for possible future use. In such case would they write Headley Brothers, Ashford, Kent, as soon as possible, and in any case within three years of their first being used.

THE attention of members is drawn to the EXCERPT $A M E D I C A$ Section XI which is a most valuable international abstracting service as it gives each month abstracts of all the important papers in Oto-Rhino-Laryngology. The subscription is $£ 48$ s. od. a year and the agents for Great Britain, the Dominions and the Commonwealth (excluding Canada) are E. and S. Livingstone Ltd., I6 and $I 7$ Teviot Place, Edinburgh. We regret that in previous issues the price was incorrectly stated as five dollars or the equivalent.

IT gives us great pleasure that Mr. Victor Negus has been designated for the honour of Knighthood and we offer him our congratulations. Not only has Mr. Negus enriched Laryngology by his many brilliant contributions but he has for many years been associated with this Journal, for some time as an assistant editor and more recently in an advisory capacity.

\section{ROYAL SOCIETY OF MEDICINE}

THE programmes of the March meetings of the Sections of Otology and Laryngology are expected to be as follows:

Section of Otology, meeting on Friday, March 2nd, 1956, at 10.30 a.m.

Discussion, "The preservation of cochlear function in the treatment of Ménière's disease". Openers: Mr. Roland Lewis, Mr. M. Spencer Harrison, Miss M. R. Dix, Mr. T. E. Cawthorne.

Section of Laryngology, meeting on Friday, March 2nd, 1956, at 2.30 p.m. Discussion, "Cancer research: its present trends". Openers: Professor A. Haddow, Professor G. Hadfield, Dr. P. R. Peacock.

\section{BRITISH ASSOCIATION OF OTOLARYNGOLOGISTS}

Anterior Poliomyelitis and Ear, Nose and Throat Operations THE attention of members is drawn to the Medical Memorandum on Poliomyelitis, No. $93222 / 7 / 63$, dated July, I954, issued by the Ministry of Health 


\section{General Notes}

and Department of Health for Scotland. The relevant passages in this report, which are of interest to Otolaryngologists, are as follows :

I. Eprdemiology.

(a) The present evidence suggests that the portal of entry is usually the mouth and that the primary site of infection is in the mucosa of the oropharynx or the small intestine.

(b) In bulbar poliomyelitis following tonsillectomy it seems that the virus most probably travels to the medulla along the cranial nerves supplying the pharynx.

(c) It is fairly generally accepted that specific trauma, especially tonsillectomy, may precipitate paralysis.

2. Control Measures: Avoidance of Certain Trauma.

(a) Tonsillectomy. The postponement of tonsillectomy when poliomyelitis reaches unusual proportions in a locality is strongly advised, particularly because when poliomyelitis follows recent tonsillectomy, serious illness, with bulbar involvement, appears to be more frequent. The Medical Officer of Health can assist by informing local hospital authorities when and where the incidence of the disease is unusually high, so that the surgeon may then take this hazard into account before deciding to operate.

(b) Tooth Extractions. There is very little evidence that tooth extractions may predispose to bulbar poliomyelitis. Nevertheless as with ear, nose and throat surgery the possibility should be kept in mind by dentists undertaking non-urgent extractions in areas of epidemic prevalence.

\section{THE NORTH OF ENGLAND OTOLARYNGOLOGICAI, SOCIETY}

The Fifty-guinea prize for original work in Otolaryngology.

At the Ninth Annual Meeting of the North of England Otolaryngological Society at Harrogate on October Ist, a fifty-guinea prize was awarded to Mr. Robert W. Baillie of 7, Riccartsbar Avenue, Paisley, for his Paper on "Lermoyez Syndrome". The cheque will be presented to Mr. Baillie at the Society's next Meeting on March 24th in Newcastle.

\section{OTOLARYNGOLOGY LECTURES I956}

THE following lectures, arranged jointly by the Royal College of Surgeons of England and the Institute of Laryngology and Otology will be delivered in the Lecture Hall of the College at 5.30 p.m.

I956

March Ist. Dr. C. Worster-Drought. Certain aspects of speech disorders in children. April 5th. Mr. T. Holmes Sellors. Perforations of the air passages and the œesophagus.

May 3rd. Mr. E. J. Radley-Smith. The physiology and pathology of the pituitary gland.

July 5th. Professor W. V. Mayneord. Recent scientific development in radiotherapy. 


\section{General Notes}

\section{MEDICAL RESEARCH COUNCIL}

\section{Alexander Pigott Wernher Memorial Travelling Fellowships in OPHTHALMOLOGY AND OTOLOGY, I956-57}

The Medical Research Council invite applications for Travelling Fellowships in Ophthalmology and Otology for the academic year 1956-57, for which special provision has been made by the Alexander Pigott Wernher Memorial Trustees. Under the terms of the bequest from which these awards are made, the funds are to be applied "towards the prevention and cure of blindness and deafness in the United Kingdom and British Empire and in particular research in connection therewith by financing medical men and students within the Empire to study methods and practices in all countries of the world".

These Fellowships are intended for suitably qualified medical graduates who are likely to profit by a period of work in Ophthalmology or Otology at a centre abroad before taking up positions for higher teaching and research in these branches of medical science. Candidates will be required to submit an outline of their proposals for work at a selected centre. The awards will normally be tenable for one year: no provision can be made for travelling grants for shortterm visits abroad.

The Fellowships provide for the payment of a maintenance allowance at the rate of $£ 65^{\circ}$ per annum for a single Fellow or $£ 900$ per annum for a married Fellow, subject to appropriate adjustment in the case of Fellowships tenable at centres outside the sterling area; in addition, an allowance is made for travelling and other approved expenses.

Forms of application for these Fellowships may be obtained from the Secretary, Medical Research Council, 38, Old Queen Street, London, S.W.I, with whom applications must be lodged by the 31st March, 1956. 
ELECTRIC 1954 model designed for use in explosion prone atmosphere.

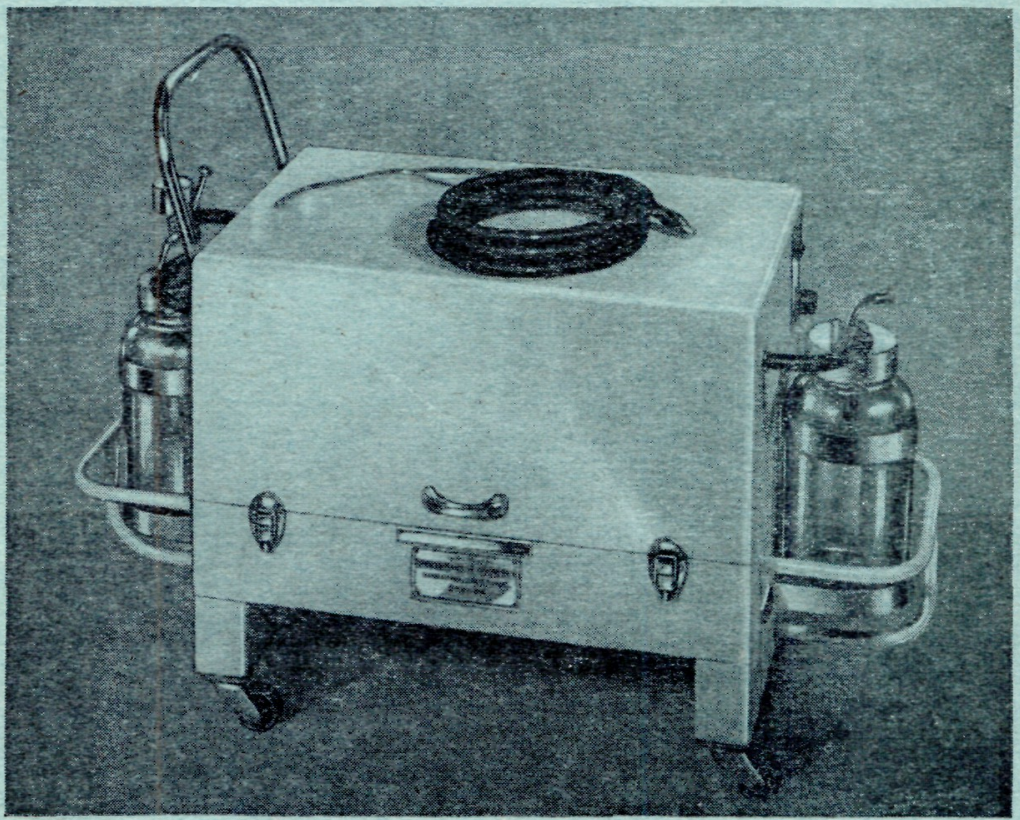

Foot Model, in case of electric supply failure.

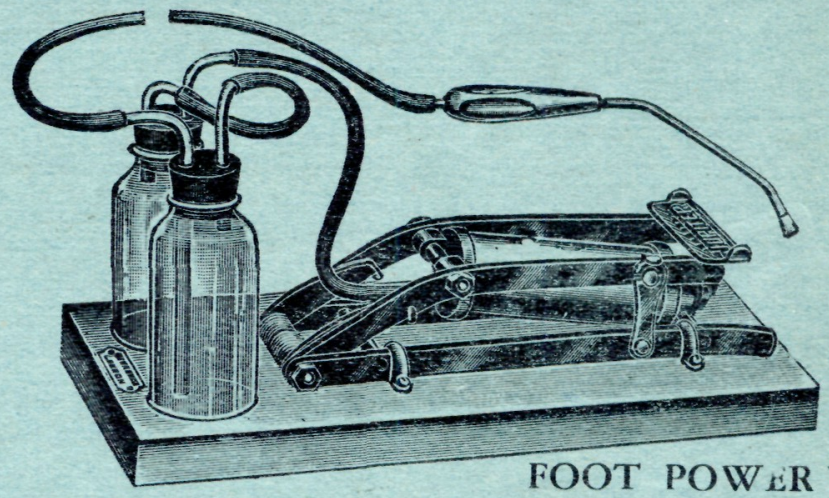

\section{SUCTION APPARATUS}

Particulars on application

\section{DOWN BROS. \& MAYER \& PHELPS Ltd.}

Head Office: 92-94 Borough High Street, London, S.E.1 HOP: 4141 Showrooms: 32-34 New Cavendish Street, London, W.1 WEL: 3764 